\title{
Article
}

\section{The marketisation of the English higher education sector and its impact on academic staff and the nature of their work}

Taberner, Andrea M

Available at http://clok.uclan.ac.uk/21539/

Taberner, Andrea M (2018) The marketisation of the English higher education sector and its impact on academic staff and the nature of their work. International Journal of Organizational Analysis, 26 (1). pp. 129-152. ISSN 1934-8835

It is advisable to refer to the publisher's version if you intend to cite from the work. http://dx.doi.org/10.1108/ijoa-07-2017-1198

For more information about UCLan's research in this area go to http://www.uclan.ac.uk/researchgroups/ and search for <name of research Group>.

For information about Research generally at UCLan please go to http://www.uclan.ac.uk/research/

All outputs in CLoK are protected by Intellectual Property Rights law, including Copyright law. Copyright, IPR and Moral Rights for the works on this site are retained by the individual authors and/or other copyright owners. Terms and conditions for use of this material are defined in the policies page. 


\section{emeraldinsight}

\section{International Journal of Organizational Analysis}

The marketisation of the English higher education sector and its impact on academic staff and the nature of their work

Andrea Mary Taberner,

\section{Article information:}

To cite this document:

Andrea Mary Taberner, "The marketisation of the English higher education sector and its impact on academic staff and the nature of their work", International Journal of Organizational Analysis, https://doi.org/10.1108/lJOA-07-2017-1198

Permanent link to this document:

https://doi.org/10.1108/lJOA-07-2017-1198

Downloaded on: 06 February 2018, At: 04:26 (PT)

References: this document contains references to 0 other documents.

To copy this document: permissions@emeraldinsight.com

Access to this document was granted through an Emerald subscription provided by emerald-srm: 405310 []

\section{For Authors}

If you would like to write for this, or any other Emerald publication, then please use our Emerald for Authors service information about how to choose which publication to write for and submission guidelines are available for all. Please visit www. emeraldinsight. com/authors for more information.

\section{About Emerald www.emeraldinsight.com}

Emerald is a global publisher linking research and practice to the benefit of society. The company manages a portfolio of more than 290 journals and over 2,350 books and book series volumes, as well as providing an extensive range of online products and additional customer resources and services.

Emerald is both COUNTER 4 and TRANSFER compliant. The organization is a partner of the Committee on Publication Ethics (COPE) and also works with Portico and the LOCKSS initiative for digital archive preservation.

*Related content and download information correct at time of download. 


\title{
The marketisation of the English Higher Education sector and its impact on academic staff and the nature of their work
}

\begin{abstract} different English universities. The study was conducted between November 2015-April 2017. by non-probability sampling, included professors, principal, senior and lecturers, and associate lecturers.

1. Efficiency and quantity over effectiveness,

2. Autocratic, managerialist ideology over academic democracy and debate,

3. Instrumentalism over intellectualism

4. De-professionalisation and fragmentation of the academy

5. Increased incidence of performativity, bullying and workplace aggression

6. Work intensification
\end{abstract}

Purpose- The purpose of the empirical study is to investigate whether, the impact of the marketisation of the English HE sector on academic staff and the nature of their professional work, are felt to the same degree in

Design/methodology/approach- Using the interpretivist paradigm, a qualitative, inductive approach is adopted. Twelve semi-structured interviews of 60-90 minutes each conducted with academics of six English university types (ancient, old and new civics, plate-glass, technological and Post 1992). Participants, who were identified

Findings- Six key themes emerged regarding the impact on academic staff and their work. The themes include:

The ancient university is least impacted by marketisation in terms of academic staff and the nature of their work. Next are the old and new civic universities, then the technological, plate-glass. The most impact is felt by academics (and the nature of their work) in the Post 1992 universities.

Research limitations/implications-There is a relatively small number of interviews in this study, therefore it is difficult to categorically correlate an academic biography with their opinion in the context of their university type. More male than female participants were interviewed. International staff were not interviewed, these could bring a varying perspective to the narrative found in this study. A mixed approach in further research would aid this objective. Some of the questioning in the pilot study was not as focused as any further primary research would have to be.

Originality/value- A further area of study, which could have practical implications, add originality and value would be to investigate how good practice in 'employee engagement' in the university context might pave the way forward. This has the potential to benefit academic staff directly and the institution, a win-win solution for all stakeholders.

Keywords-Neo-liberalism, New Public Management, marketisation, corporatization, managerialism, performativity, commodification, targets and terror, surveillance, de-professionalisation, occupational stress, workplace intensification, workplace aggression and bullying.

Paper type- Research paper as part of DBA studies at Lancashire Business School 


\section{Introduction}

There is a new global economic order underwritten by free markets, multi-national corporations and the increased mobility of capital and labour. Similarly, since the 1980s, the well-documented UK narrative is one of neo-liberal economic policy. Over the last decade, there have been cutbacks in the public sector. Efficiency, cost effectiveness are the main priorities of the new public management (NPM). Workers' rights, pay, pensions, conditions, and bargaining power have diminished. Public sector organisations have adopted structures, processes, management practices and values (more commonly found in the private business sector), with the objective to make their organisations run better. Public managers and bureaucrats have simultaneously introduced an unprecedented network of controls.

Universities are not exempt from this. The UK higher education (HE) context includes further complications of massification since 1990s and the introduction of student tuition fees in 1998. Since 2006/7, higher education students are now 'customers', degrees are 'products' and there is fierce competition for ever decreasing resources. The ascendancy of metrics and performance indicators, commodification and performativity has many intended and unintended consequences. One of these is significant occupational stress among many of those working in universities (THES Annual Work-based Survey 2016; Alvesson and Spicer 2016; Visser 2016; Lynch and Ivancheva 2015; Parker 2014; Kilkauer 2014; Thompson 2013; Kinman and Wray 2013).

\section{Literature Review}

The neo-liberal context

Universities have changed over recent decades resulting in a major transformation of ethos in higher education (HE), from essentially a collegial, to a managerial one. This is because of the dominance of neo-liberalist ideology (Docherty 2015, Grey 2013).

Neo-liberalism is a universal phenomenon; it is an approach to economics, which seeks to explain the workings of complex market economies in an era of globalisation. According to Cairns and Sliwa (2008:6), globalisation is underpinned by the advancement of neoliberalism.

The primary goal of neo-liberalism is to commodify resources (Waring 2013). State-funded institutions are seen as inefficient, unresponsive, in need of 'market' discipline, and so liable for hyper-commodification. The objectives of neo-liberal policy seem to be focused on benefiting managers, and promoting capital accumulation. Indeed, (in Molesworth et al 2011:73) Sauntson and Morris argue that, UK universities in 2009 'became the provenance of the newly formed Department for Business, Innovation and Skills (BIS)'. The fact that there is no mention of education in its title at all is surely not a coincidence. Consequently, the neoliberal priority over education, academics would argue, is often to the exclusion of pedagogical matters. There is a significant and 'growing divide between an academic labour force and a neo-liberal managerial elite', echoing 'a growing proletarianisation and commodification of academic work' (Waring 2013:415).

The rise of the neoliberal 'Evaluative State' (Kehm and Teichler (ed.) 2013, Neave 1988) and 'quantified control' (Burrows 2012), which have led to an academic 'mental assembly line' (Gilbert 2010; Fisher 1994), is evident in the literature. This means the subordination of 
academic activity to commercial goals, the shift from exchange to competition, the movement from equality to inequality, and the turning of academics into human capital. These are the key features of neo-liberalism in universities (Berg et al. (2016). For many academics, these processes are experienced through 'audit cultures' (Strathern 2000), and rituals of verification with which the academic workload is increasingly understood. Ironically, this is what HEFCE criticises as the 'metric tide' (Wilsdon 2015). Wilsdon continues: 'Metrics hold real power; they are constitutive of values, identities and livelihoods.' This is correlated to the demise of the Keynesian 'social contract' and welfare state (1940s-1970s) where demand-side macroeconomic policy was interventionist, democratic and social (Cate 2013 in Farnham 2015a) - hence the establishment of the NHS, income maintenance, social housing and education for all.

In sharp contrast, since 1980s the opposing supply-side macroeconomic policy prevails. This is the so-called 'neoliberal settlement', which is underpinned by political systems all over the world (Farnham 2015b, Steger 2010). Priorities here are the free market, continuous economic growth, productivity, efficiency, competition, individualism, deregulation and the privatisation of state assets.

Davies (2016) asserts that neo-liberalism is economically deemed a failure. He says we need to consider alternative approaches. Others (Farnham 2015b; Horton and Farnham 1999) argue that it is fundamentally politically driven. Its political goal is to shrink the state using the pretext of austerity measures. Austerity capitalism causes human labour's exploitation, degradation and human suffering (Hill ed. 2013). Hill (ed.) 2013:3 argues that the 'neoliberal project provides capital with the political and ideological muscle to both construct consent and silence dissent'. Under the 'white heat of neo-liberalism' (Granter 2009) consumerism dominates and controls the consciousness of the populous, and their identity so much so that, they do not question any political or economic alternative (Docherty 2015, Jones 2014, Ritzer 2013). Therefore, there is no real resistance to the status quo. As Dillow (2007) laments, it is the end of politics.

\section{New Public Management}

NPM is a term coined by Hood (1991) for the policy to modernise the public sector and render it more effective. The basic idea of NPM is that market-oriented management of the public sector will lead to greater cost-efficiency, without having negative side-effects on other considerations. However, Lorenz (2012) argues that, NPM policies employ a discourse that parasitises the everyday meanings of their concepts - efficiency, accountability, transparency, and quality - and simultaneously perverts all their original meanings. NPM has not proved to have anything, but financial gains, creating efficiency for government, at the expense of society and effectiveness within the public sector. The economic NPM definition of education ignores the most important aspects of the education process, and therefore poses a fundamental threat to education itself (Docherty 2015).

Under these policies, workers have lost power and control in the face of threats of redundancy and have just become pawns in the 'corporate card game' of capital, and its agents (Grey 2013). Follett (1940 [1918]) advocates power with, rather than over the workers. Many critical management writers challenge the politics and realities of NPM (oppression, exclusion) and its links to neo-liberalism, in favour of an emancipatory agenda of fairness, ethics and moral organisation. As Grey (2013:119) asserts, 'we have been quietly mugged over the last 40 years'. 
Ferlie et al. (1996) describe 'NPM in Action' as involving the introduction into public services of the 'three Ms': markets, managers and measurement. However, many would argue that universities have a long history and a civic role to play, not just an economic one (Docherty 2015). They serve as an anchor embedded in civic life. That is why many universities have charitable or not for profit status (Thomas $6^{\text {th }}$ April VC Address at UCLan 2016).

For Lorenz (2012: 629):

'All things considered, we should expect that as long as organizations continue to be controlled in accordance with the discourse of NPM, management will continue to produce NPM bullshit, and professionals will continue to react with cynicism, hypocrisy, and dissidence, as was the case under state Communism..... The neoliberal NPM dream is the privatized versions of economic and bureaucratic totalitarianism.'

Managerialism

Managerialism has different meanings to different authors (Teelken 2012:273). Nevertheless, the most succinct definition is that of Pollitt (1990:1). He believes it is a set of beliefs and practices, at the core of which, burns the seldom-tested assumption that better management will prove an effective solvent for a wide range of economic and social ills.

According to Kilkauer (2013) managerialism is not primarily concerned with political issues but rather the management of capitalism and society in its image. Klikauer describes management as an early $20^{\text {th }}$ century term (Taylor, Fayol, Ford), while managerialism is a late $20^{\text {th }}$ and $21^{\text {st }}$ century term. It merges ideology with management (its origins) plus a third ingredient: expansion. Its objective is 'to expand managerial techniques far beyond the realms of organisations, spreading managerialism into the wider economic, social, cultural, and political sphere '(2013:3).

Managerialism is a 'belief in or reliance on the use of professional managers in administering or planning an activity. ... During the 1980s a new species of managerialism moved into companies and into research management.'

(www.en.oxforddictionaries.com/definition/managerialism accessed 10th July 2017)

It is associated with hierarchy, accountability and measurement, and a belief in the importance of tightly managed organizations, as opposed to individuals, or groups that do not resemble an organization.

The popular concept of 'managerialism' appears to share some characteristics with the pejorative use of the terms: bureaucratization, centralisation, standardisation and instrumentalism. Grey (2013:63) calls it 'enhancing efficiency through management control'. Parker (2014:290) speaks out against 'performance indicator managerialism', which is full of paradoxes.

By contrast, a pro-managerialism perspective is suggested by the unusual findings of Marini. Marini argues in his study (2015) of 26 universities across Europe, that university managerialism can boost academic freedom and collegiality (THES $21^{\text {st }}$ August 2015). However, his argument is nuanced. He says trust is something that can be destroyed, or cultivated by managerialism. Even Marini's study indicates that a cynical explanation why the two organisational styles (collegialism and managerialism) might happily co-exist, is that 'nothing gets academics working together better than a shared hatred of management'. In the 
same THES article Shattock says that when managerialism penetrates downwards into and through academic heartlands, it changes the academic culture fundamentally. Palfreyman (2007:135) said that while managers now run the big and important stuff like budgets, marketing... strategic direction, collegial decisions still steer lower-level academic units. He continues: 'only in the very highest ranked institutions globally, are the academic lunatics still in charge of the asylum, because academics at these elites cannot be treated badly given that they are internationally mobile.' The implication here being that academics in non-elite institutions can be treated badly by managers, as they have no alternative, but to stay and endure.

\section{The consequences}

In the context of UK HE sector, neo-liberalism, NPM, managerialism, capital's tactical weapons of rationalisation, deskilling, redundancy, contingency, outsourcing and automation' (Ovetz 2015) are used to seize 'quantified control' over the academic workforce. 'The academic must become a generic, functional worker who fulfils a full talent matrix and facilitates the flow of capital' (Morrish 2016). This is what Bendix-Petersen and Davies (2010) describe as 'biopower'.

How managerial practices are to be implemented, is open to debate. Chandler et al. (2002) argue that hard managerialism has a human cost; they recommend a softer, more collegial method of management. A Guardian Survey (2014) shows that there is concern around a 'bullying culture', brought about by managerialism, job insecurity and a culture of long working hours. A pressure to publish is felt by more than a third of 25-35 year olds. It is believed that, these conditions are to blame for mental health problems among academics. 'Senior lecturers and those aged between 55-64 years feel most strongly about this connection'.

Much of the Critical University Studies (CUS) literature alludes to the academic under siege. It frequently uses the metaphor of combat, battle and warfare. Examples of these are: 'universities at war' (Docherty 2015; Giroux 2014), 'theatres of cruelty' (Couldry 2008), 'a new barbarity' (Williams 2016; Morgan 2015), the 'terror of performativity' (Wilson and Holligan 2013) 'decimation of a profession' (Gill 2009) and 'degradation of work' (Thompson and Smith 2010). In addition, Berg and Seeber (2016: x) claim that a 'language of crisis dominates the literature on the corporate university.'

Other consequences with regard to academic work emphasise change, conflict, contestation, intensification, stress, pressure, increased workload, widespread unhappiness and poor staff morale. The increasing casualisation of teaching staff is of concern to many in the profession. According to the UCU April 2016:1 report on 'Precarious work in Higher Education', '54\% of all academic staff and $49 \%$ of all academic teaching staff are on insecure contracts'. In addition, Berg and Seeber (2016: $\mathrm{x}$ ) refer to the 'frantic pace and standardization of contemporary [academic] culture', as a direct result of the corporatisation of universities, which 'has compromised academic life and sped up the clock'. Young and Beck (2005:184) talk of alienation and anomie; they describe 'a generation of practitioners (who) have experienced what is, to some a sense of crisis and of loss. Cherished identities and commitments have been undermined and, for some, this has been experienced as an assault on their professionalism'. 
Some literature relates to the debate about how academics respond to, and deal with the new managerialism (Teelken 2012, Ackroyd and Thompson 2012 [1999]). Academic active resistance to managerialism can take the form of passive, covert resistance, which appears to be the most common form, as opposed to overt resistance. Teelken refers to symbolic compliance, professional pragmatism and formal instrumentality. Diefenbach (2009:15) claims subversion refers to the way academics 'learn to play the game or system'. Evidence shows that academic resistance is often not confrontational, as avoidance strategies or covert defiance: 'I forgot', 'going off sick', and partial compliance (all of which are examples of non-confrontational resistance) are regularly used to great effect.

Bok (2003), a former President of Harvard University, recommends deferring to academic judgement when decision making in the HE context. Bok says that undermining academic standards, the intangibles, (Bok 2003:108) and allowing money, the tangible, and profit to dominate is extremely foolhardy. Bok warns that although 'faculty....moral education of students....trust of the public are all intangible and remote... and may never materialise, at least not for a long time, it is all too easy to overlook them' (Bok 2003:119).

Academics as subjects of neo-liberalism

Academics, can exercise some degree of 'technical control' over their work, but are losing 'ideological control' (Miller in Smyth (ed.) 1995: 40-59) and academic freedom (Karran and Mallinson 2017). The state, institutional managers and bureaucrats have extended their 'quantified control' (Burrows 2012). There is incessant surveillance, external and internal scrutiny (Overtz 2015, Lorenz 2012, Foucault 2008) over funding, structures, systems, processes, via a range of metrics embedded in an audit culture (workload models, demand for data assemblage, national student survey, research assessments, league tables, the TEF to be introduced 2018).

Since the introduction of electronic locks, [an example of management Foucauldian panoptical surveillance] 'we can only enter the building and the classrooms when the computer allows us to. Nothing makes the relevance of Harry Braverman's analysis of the division of labor more relevant than being an adjunct professor - a highly autonomous but anonymous and interchangeable mental worker' (Ovetz 2015:275). 'Management has become administration, which is a labor process conducted for the purpose of control within the corporation' (Braverman 1974:267). This is termed by Derber (1983) as the 'ideological proletarianisation' of academic work.

Martin (2016) describes the 'creeping bureaucracy' and 'rationality' of management together with constant game playing around metrics in research as key stressors for many academics who feel overburdened. This has resulted in the loss of autonomy and, control over the shaping of how many aspects of academic work is to be done, which is the most important characteristic of a profession (Lorenz 2012). Gill (2009) talks of the decimation of the academic profession. Morrish (2016) quotes Williams, former Archbishop of Canterbury, who has spoken of the 'new barbarity' in British universities.

Emphasis today in HE is on performativity, commodification. The discourse of NPM dominates which dehumanises academics and brutalises the HE work context. Performativity is a form of incentive, control, and attrition based on rewards and sanctions (Kallio et al. 2016; Ball 2003:216). It terrorises (Lyotard 1984) employees in the public sector. It regularly puts them under undue pressure and distracts them from their actual work. 'Academic endeavour is not something that can just be improved by order' and infers that it involves ethos, judgement, time and space, support (Morrish 2015). In addition, there is too much 
focus on the how, the quantitative aspects of academic labour process rather than the why, the qualitative aspects. Outspoken Professor Docherty (2015) against management details the 'illocutionary silencing' and threatening of academics when he experienced suspension for a year by the directorate.

Universities are complex, multifaceted and diverse organisations. Within a performative regime, however, it is likely that policy drives market-driven priorities. Therefore, claims, Ball (2003:224), performativity is promiscuous. This results in acts of fabrication. These become embedded, reproduced by systems of recording and reporting on practice. Anything, which does not 'fit' into what is intentionally to be represented, is discarded and excluded. Performativity is full of paradoxes. It is a vehicle for changing what academic work and learning are. Lyotard (1984) argues that the commodification of knowledge is a key characteristic of what he calls' the post-modern condition.' Within the public sector the desocialisation and externalisation of knowledge has involved a seismic shift in the nature of workers and their work. In other words, 'service' commitments no longer have value or meaning, and professional judgement (discretion) is subordinated to the requirements of performativity. Here is where Ball notes the element of 'cynical compliance', which comes into play, in the processes of individual and institutional fabrication. This is referred to as 'hyper-reality' (Baudrillard 2000 [1970]).

The role and professional survival of academics has become dependent on fulfilling establishment norms (Tapper and Salter 1995). This instability, loss of control and status, ambiguity of the academic profession, worsened in the 1990s and accelerated in pace since 2006. This has resulted in a de-professionalisation of the largely frustrated academy and a fragmented, isolated professional disparate community with an identity crisis with no real voice.

HE is now controlled by managers, otherwise known as 'agents of capital' (Thomas 2003:26), and bureaucrats. Their role is to extract the maximum out of each employee while at the same time rewarding them for their efforts at the lowest possible wage. Academic salaries have fallen in real terms over many years (www.theguardian.com > Society > Public sector pay $3^{\text {rd }}$ July 2017). In addition, there is a UK university pension scheme deficit of $£ 12.6$ Billion in 2017 (www.thetimeshighereducation.com/news/uk--university-pensionscheme-deficit 26th July 2017).

Bathmaker (1999) examines the unwritten 'psychological contract' (Rousseau and WadeBenzoni Model 1994) between managers and academics in a post 1992 university. This has dramatically changed from a 'relational contract' (Wilson 1991; Winter 1995), based on trust, fair play, equity, ethics, respect for professional judgement and reciprocity, where employment tended to be continuous and predictable, to a transactional [business] contract, one which is de-personalised.

Even as far back as 1965 Schein warned that, 'if a university... withholds status of privileges such as academic freedom and expects faculty to obey arbitrary authority, it will be violating its psychological contract, resulting either in redefinition of the contract....or an alienation of the faculty'. This is exactly what has happened.

What is critical is the how the academic labour process is enacted, and in whose interests. These go to the very heart of how knowledge is produced, and how it is conveyed in our universities (Smyth 1995). Noteworthy is that the Haldane Report (1918) was designed to protect universities from government control. However, since the 1990s the OECD has a 'human capital' view of higher education. The origins of the restructuring of $\mathrm{HE}$ in Western 
countries can be traced back to this. The OECD claims the role of education lies squarely in the contribution it can make to international economic reconstruction and competitiveness, through:

- Producing more' flexible' and 'responsive' forms of labour;

- Fostering greater participation by the private sector in higher education, especially through research;

- Requiring that HE operate more like the private market (Smyth ed.1995:3)

As Neave (1988) concludes, the changing boundary between state and higher education offers a more robust explanation. Much of this shaping of the academic labour process, (academic marginalisation, casualisation of teaching, research targets, outputs and funding) are controlled by managers and bureaucrats. Jobs have become more insecure. Consequently, there is internal fierce competition resulting in winners and losers within the academy. Relations between colleagues and their line managers have become more adversarial, and the once collegial, collective community within academia has suffered.

Many writers describe the new HE work atmosphere as toxic (Morrish 2015). This toxicity is referred to as the theory of 'organisational miasma', a theoretical concept that describes a contagious state of pollution - material, psychological and spiritual.

Impact on the academy

The term, stress, is not consistent in the literature. Cohen et al. (1995:3) provide a comprehensive definition of stress as a process in which "environmental demands tax or exceed the adaptive capacity of an organism, resulting in psychological and biological changes that may place persons at risk for disease.' This generates cortisol, rather than the performance enhancing stress hormone adrenaline. Cortisol is a harmful hormone released at times of extreme and prolonged exposure to stress. Lazarus (1990) says that stress is a condition or feeling experienced when a person perceives that demand exceeds the personal and social resources, when an individual is unable to mobilise. Stress has reached epidemic levels in the $21^{\text {st }}$ century society (BBC 1 Documentary $4^{\text {th }}$ May 2017). Chronic stress, where an individual is in a state of stress over a prolonged period, can cause cancer, immune or heart problems and mental breakdown.

Many studies have identified academic key stressors. These include: reductions in funding, relatively low salaries, heavy workloads, long working hours, poor work-life balance, significant growth in student numbers, poor communications, role ambiguity and striving for publications (Berg and Seeber 2016; Kinman and Wray 2013; Archibong et al. 2010; Kinman 2008; Tytherleigh et al. 2005; Rutter et al. 2002; Winefield et al. 2003; Winefield and Jarrett 2001; Fisher 1994). A substantial literature over the past five decades has consistently shown that work stressors for academics cause illness and reduce productivity at work. Studies indicate that occupational stress has significantly increased in the HE sector. The first comparison of stress levels in different HE sectors suggests that academics working in the UK and Australia experience significantly more stress, than in Germany (THES $4^{\text {th }}$ May 2017; Geppart \& Hollinshead 2017). Interestingly, Germany's HE sector is still state-funded and not marketised. This study was conducted by Professor Persson who said that the deterioration [in staff well-being] between 2006 and 2010 in the UK mainly due to the REF, high workloads and poor management especially in the Post 1992 universities has been remarkable. 
In the University Workplace Survey 2016, 51\% of academic staff claimed that their job has a negative impact on their health. Many anticipate not being able to sustain the current levels of unmanageable workload and occupational stress until retirement. One professor working in humanities at a plate-glass university says, 'Staff are being worked to their limits and the university is taking advantage of the workload models, which in themselves are horrendous tools to make us work even more' (THES $4^{\text {th }}$ Feb 2016:42) .

Unattainable targets lead to unmanageable levels of stress (Morrish 2015). Gill talks of work intensification and extensification, in other words 'academia without walls' (2009). There are no longer boundaries for the work. This is referred to as the 'shifting and creep of academic work'. This seeps 'into vacations at the beach or campground'. Furthermore, we have the redefinition of the academic workplace and the transformation of cyberspace into workplace. Today workplace is anywhere and anytime: 'one can be connected to a network or the internet' (Petrina et al. 2015:60-62). The management's construction of the ideal employee is one who is compelled never to rest (Davies and Petersen 2005:89). Nevertheless, employers have a legal obligation to conduct risk assessments and prevent known causes of stress. 'We [as academics] need decency, humanity, respect and trust [shown to us by managers]', implores Morrish (2015). After all, universities 'are people-dominated organisations. So getting it right, with respect to staff, matters' (Propper 2013: www.the guardian.com).

Workplace bullying is most recently defined as workplace interaction consisting of any combination of harassment, discrimination, social exclusion, public and professional humiliation, criticism, intimidation, psychological and sometimes physical abuse that occurs repeatedly and over a period of at least six months (DeFalco and Crabb 2015; Roderick 2016).

'Research continues to address the causes of bullying, but perhaps surprisingly those investigating it are themselves operating in a risk sector as high levels of bullying are consistently reported in higher education. In the UK, the overall prevalence of workplace bullying, based on the proportion of working people, who have experienced it, across all working sectors, is estimated at between 10-20\%. However, the percentage of people who have experienced bullying within academic settings is higher than the national average. UK higher education studies have found the percentage of people experiencing it ranges between $18 \%$ and $42 \%$ ' (The Guardian $3^{\text {rd }}$ Nov. 2014).

A closer inspection of bullying in academe can provide clues as to why it occurs. Cultures where bullying flourishes have been characterised as competitive, adversarial and politicised. Perhaps this is best illustrated by the bullying behaviours most cited within academic contexts, for example: threats to professional status and obstructive behaviours, designed to inhibit employees achieving their goals.

Current literature surrounding the workplace experiences of English academics does not explore these in a variety of English university settings. The researcher believes that the impacts are felt to varying degrees' dependent on English university type (Farnham (ed.) 1999:209), and the biography of the academic within them could determine a varying perspective. 


\section{The Study}

This study was conducted between November 2015-April 2017 to investigate the marketisation of the HE sector and its impact on academic staff and the nature of their professional work in a variety of English university settings.

Design/Methodology/Approach

Using the interpretivist paradigm, an inductive approach was deemed the most appropriate for this study. Twelve semi-structured interviews of 60-90 minutes, each with staff from six different English universities, were undertaken. These participants were identified, by nonprobability sampling methods, namely: snowball sampling. The interview schedule was piloted.

Farnham's (1999) historical classification of English universities was employed. This includes six typologies, which are:

1. 'ancient universities'

2. 'old civic universities'

3. 'new civic universities'

4. 'plate-glass universities'

5. 'technological universities'

6. 'post-1992 universities'

Prior to all interviews, all participants were sent a 'Research Participant Information Sheet' (explaining what the aims of the research were, with data and storage assurances), together with a 'Consent Form', which they were requested to sign, if they were happy to take part.

Most interviews were face to face with the exception of four of the twelve, which were conducted by telephone. The roles of participants included professors, principal and senior lecturers and, associate or also known as hourly paid lecturers/ Oxbridge college level teachers (who exclusively only teach). Anonymity and confidentiality were assured. Most interviews were recorded with the permission of the interviewee, then transcribed. Only four were not, but extensive notes were taken with permission.

In order to minimise insider researcher-bias the same open questions were asked of every participant.

Data Findings, Analysis and Discussion

Observed Behaviour of Interviewees:

Interviewee behaviour ranged from calm, reluctant resignation and sadness about the current context of HE sector in England, through to intense frustration, anger and emotional distress. The meaning and significance of this, the researcher believes, is that the whole subject of the impact of marketisation on HE for many academic staff, regardless of institution type, is very emotive. Some more extreme behaviour was noted in the cases of plate-glass, technological and post 1992 universities. In one case, the interview had to be halted for a short break and resumed after the candidate had regained her composure and expressed her desire to continue. 
In addition, an Oxbridge Professor became angry, when he reflected on the bureaucratic quality control aspects of academic work and the 'grossly underfunded British universities', over recent years.

Largely, feelings ran high on the issue of the marketisation of the UK HE sector in many interviews, regardless of university and academic biography.

\section{Biography of Interviewees and Associations with Marketisation of HE sector}

Participants included academics at all levels from a variety of disciplines: Languages, Literature, Philosophy, Business and Management. The academic staff interviewed were from all six types of university in England. All members of staff were British. This was not deliberate on the part of the researcher.

It appears that the longer serving older staff members regularly talk of a feeling of 'being trapped' in the profession. If they were to leave, they would jeopardise their pensions and what are they otherwise qualified to do. These staff, regardless of university have experienced different 'better' times in HE were more critical, frustrated and cynical of the marketised context of HE, than younger members of staff. These were more accepting of the current context and less critical.

However, younger staff, under 40 years of age especially, but not exclusively, in Post 1992 universities, did express how pressured they felt. These sentiments were summarised by one young Post 1992 interviewee, 'the insecurity of my professional status, the pace of work and pressure to publish was in the longer term unsustainable for my health and well-being, but at the same time I am glad to have a job. I suppose I should have a plan B if things continue to get worse.'

Those staff who worked in insecure posts felt 'their positions to be precarious' and therefore many could see only a few and highly sought after opportunities to enter the profession as a permanent member of the academic staff. Essential requirements for academic job applicants have risen sharply in recent years. Basic requirements are: a $\mathrm{PhD}$, teaching qualification, professional affiliations and a substantial list of publications, just to start on the bottom rung. For many 'the pay would not be much more for a permanent position and starting an academic pension at $40+$ years of age on an average salary did not provide a positive prospect, 'says a plate-glass staff member. Many of these casual staff, regardless of university type, felt stressed and demoralised. These staff were mature in their $30 \mathrm{~s}-40 \mathrm{~s}$ with no chance of financial stability to enable them to get a mortgage.

In sharp contrast, although no so-called 'super profs' with celebrity status like Professor Cox commanding enormous salaries were interviewed here, reference was made to these by one interviewee from an old civic university. 'His celebrity status enhances the reputation and attracts science students' to his institution. 'There has been a growth in the super professors and an explosion of salaries' asserts an academic from a plate-glass university. This phenomenon was referred to, by the afore-mentioned interviewee, as the direct result of marketisation in HE. Figure 1 below provides an overview of the six key themes in this study. 
Figure 1: An overview of the six key themes of the impact of marketisation of HE sector on academics and the nature of their work, which emerged during the pilot study

\begin{tabular}{|l|l|}
\hline 1. & Efficiency and quantity over effectiveness and quality \\
\hline $\mathbf{2 .}$ & Autocratic, managerialist ideology over academic democracy and debate \\
\hline $\mathbf{3 .}$ & Instrumentalism over intellectualism \\
\hline $\mathbf{4 .}$ & De-professionalisation and fragmentation of the academy \\
\hline $\mathbf{5 .}$ & Increased incidence of performativity, bullying and workplace aggression \\
\hline $\mathbf{6 .}$ & Work intensification \\
\hline
\end{tabular}

1. Efficiency and quantity over effectiveness and quality

'Most colleagues grudgingly go along with the notion of marketisation due to economic pressures, but they are not happy', reports Post 1992 interviewee. All interviewees quote the competitive environment for fewer resources, diminished state funding, by the many institutions within the HE sector as an association of marketisation.

Scepticism among all academics with the exception of the ancient, that the quality of provision is being compromised, as a result of the emphasis on the recruitment of maximising a high quantity of student numbers, domestic and overseas, at under- and postgraduate level. Bringing in income takes priority in all decision making. 'It's like a production line, bums on seats, but some overseas students are not of a very high standard, they then fail, get poor marks or scrape a pass. This is slowly backfiring as it damages a university's reputation in the longer term' (new civic uni. staff member).

Most interviewees, reported that there has been 'a dumbing down of standards, and pressure to inflate grades by managers' which causes stress among academic staff who wish to uphold pedagogic standards and values. Many participants lamented how they referred to the fact that students are increasingly termed customers but, 'the big question is what is good from the point of view of the student (the end product-the qualification) and that of the academic (the quality of the learning process) are different....'says one plate-glass university lecturer. 'Higher education in this country is in danger of losing sight of what education is about'.

'There is no time to consolidate. Every year there seems to be a new management regime, structure, which means more wasted effort and resources. New senior managers appear every couple of years, make short-sighted decisions and leave before the implications are felt. Managers should focus on areas that are not working well', claims a Post 1992 academic.

She continues, 'There is a lot of talk about quality but the main priority of managers is to make savings at any cost and retention; it is we the academics who care about the real quality and the pastoral care of the students, which eats into our time but not reflected in our workloads. Staff do it anyway... but staff goodwill is going. There's less staff every year, lots of platitudes by managers but they don't care.' 'Administrative systems lead, rather than academic, all decision-making and change. It's a case of the tail wagging the dog...I Ifeel academics are increasingly seen as a problem to be managed.'

Those research active staff working at even professorial level 'feel under immense pressure to meet publishing targets', which some believe were not always realistically set by their 
managers and would often compromise quality by diktats of quantity. This, voiced several, 'brought forward notions of earlier than planned retirement from the profession.'

A plate-glass academic said that 'employers want both creativity and, to do what they want and, for us to follow orders and, yet the two are incompatible.'

The meaning and significance of these findings is that most staff feel there is a worrying, dumbing down of quality where student numbers and the income that follows is a priority. The growth in overseas numbers (fees are much higher than those of domestic students) seems to have an impact on the nature of academic work. Staffing is not increased by managers to help cope, as this is not financially efficient but academics in all institution types are left having to effectively deal with new pedagogical and pastoral demands on their time. HE management appear to focus too much on economic efficiencies rather than simultaneously focussing on effectiveness in the daily realities of academic work. This theme appears to be at its most severe in Post 1992 and plate-glass universities.

2. Autocratic, managerialist ideology over academic democracy and debate

There are 'too many changes due to marketisation, which remove some of the 'glue'. It then takes time to recreate relationships with new people in admin. and, colleagues' and there is 'little stability', which are reported by most interviewees regardless of institution. However, this sentiment appears to be most felt among academic staff, who work in the Post 1992 universities. They feel 'change, which favours administrators and systems over academic staff, like the centralisation of all administration, is imposed rather than as a result of consultation with lecturing staff. It does not work effectively for staff and students. 'This many feel demonstrates 'the contempt of management towards the academy and is inherent in the managerialism which dominates the Post 1992 HE institutions. If you got rid of all managers tomorrow all academic work would continue to the same high standard'. The latter two quotes are from two different Post 1992 staff members from separate institutions.

In old, new civic universities, plate-glass and Post 1992 universities, interviewees reported that $\mathrm{HE}$ 'academic managers are often much less collegiate nowadays and too remote from staff and often autocratic' (reports a plate-glass and a new civic academic). 'At times some managers are openly disrespectful towards academics' (says one old civic university staff member) and 'there were too many layers of management and administration and these were far too bureaucratic,' suggests a Post 1992 staff member. In other words, internal upward communication had become cumbersome. She continues, 'managers just talk to other managers'. As a result, academic staff feel that increasingly they have no voice. 'There is no consultation by management. They appear uninterested in the concerns of staff,' says one Post 1992 academic. Many staff believe that' managers and administrators serve their own ends but not those of academe.' A new civic academic corroborates this, and says that ' managers just pay lip service to consultation with staff.' For many there now appears to be a 'new breed of 'professional' manager elite within HE who could be equally managing a sausage factory next week as the same management approach is used. We have the standardisation of the academic production line, 'summarised by a Post 1992 academic, who has served $20+$ years in HE.

A plate-glass and separately a Post 1992 academic each say that they have witnessed to their dismay, 'young, academic managers appointed in their universities from industry who have 
little understanding nor appreciation of the nuances of the higher education sector, and who then go about dictating what is to be done about marketing and advertising, websites, allocating budgets etc.'

The meaning and significance of these findings is that, since marketisation, the academic voice has been gradually eroded by an increasingly remote management. There is little to no democracy and debate with academics in the HE sector. Decisions are simply imposed on the academics from above with little attention to the pedagogical impact. Managers seem to be superfluous to HE requirement. Managerialism seems to have infiltrated all kinds of university with the exception of the ancient. However, it appears to be as its most autocratic form in Post 1992 university.

\section{Instrumentalism over Intellectualism}

'What was routine for academics in the past and done well is now micro-managed, especially in the Post 1992 universities. Being told not just what to do but how to do it...like electronic marking...I hate it.' This makes staff feel their professionalism, is being eroded. One Post 1992 academic says, 'constant over checking by 'managers' that academic work has been done often short circuits intellectual engagement as the emphasis is on the tangible quantifiables and not on the qualitative and pedagogical aspects. The latter many feel have become undervalued by managers. The incessant standardisation and one size fits all mentality of managers behind all university policy is ridiculous. It simply does not work.'

Those interviewed from plate-glass, old and new civic universities reported that they believed there to be 'more self-monitoring and surveillance in the form of the NSS, League Tables, RAE outputs, appraisals, targets, resources and the soon to be installed TEF in Sept 2017.' This they too believed was 'a manifestation of erosion of the profession via the loss of power and control over their day to day own work, autonomy and academic freedom and status as a result of the competitive marketisation of the sector.' 'Management would say that these are like this so that the university processes are online and transparent for all to see' (reports a new civic academic).

One plate-glass interviewee highlighted that at his university 'the management listened to staff via the senate. A senate is an opportunity for academics to voice dissent and have it minuted. It is an institutional mechanism, which pushes back managerialism but, this process is being slowly eroded. The current VC is a dull bureaucrat who is unconnected to staff and students.'

Two academics from different old civic universities indicated that they were 'angry' 'galled'. They said that when they are asked by managers to focus on things (like completing some metrics to report to managers that they have done what they have been asked to do in order to fulfil some government imposed measurement) which are very time-consuming and 'detract from what they believe as academics they should be doing like researching and writing.'

Only one interviewee from an old civic university claimed that from a manager's point of view 'marketisation has been helpful to deal with some difficult staff. Often these could be those who had tenure from before the 1990s, and if they did not research enough the only sanction was to give them more teaching. Nowadays there are clear outputs on staff workloads. In the case of one old civic university 'an academic staff member must publish $3 x$ 4 * journals every 3-4 years and contribute to the RAE or leave.' In this institution, it seems 
that all permanent staff focus on research. Also, most teaching has been subjugated to exclusively temporary or fixed term associate or hourly paid teaching staff.

The meaning and significance of these findings is that instrumental targets, surveillance and constant checking of the intellectual staff by HE managers and administrators, is of concern to those in the profession. The incessant standardisation efforts of managers of university policy appears inappropriate and inflexible for many academic purposes. Too much time and effort is spent, in the reporting to management of the fulfilling of metrics rather than just getting on with the job in hand. Metrics of just the quantitative aspects of the nature of academic work seem to be the subject of much dismay among all staff, regardless of their biography, and across all institution types.

\section{De-professionalisation and fragmentation of the academy}

In all institutions staff felt, 'there is clear differentiation between managers, administrators, researchers and then the teaching staff who have relative low status', (voiced by a plate-glass academic). 'Worst of all is the position of casual staff, who are very poorly treated,' said a Post 1992 university staff member. These casual staff are a more regular feature of all university types with the exception of the ancient university. Job insecurity was the main conversation topic of those interviewed who were non- permanent teaching only staff on temporary and fixed term contracts. In Post 1992 universities many staff observed that as permanent staff either retired or left, they were not replaced with the like but, instead with temporary or even hourly paid teaching staff were hired instead. Reports of increased casualisation and marginalisation of teaching staff, claimed by most interviewees regardless of institution type, with the exception of the ancient universities. However, even there, Oxbridge college level teachers did much of the teaching while research was the preserve of the permanent academic staff.

Interviewees report a division of staff into two clear camps of 'winners and losers'. 'Those academic staff, the star researchers who bring in huge bid monies, have everything to gain, promotion, status, sabbaticals from the new marketised context. Then there are those, mainly teaching staff with relatively low status, who cannot thrive in such a context (but are essential to uphold a learning environment for students) whose priority is not measurable but qualitative in their pastoral and nurturing role. Researchers have currency and value and build their careers on reputation through their work. Academic managers too are winners as they too have a vested interest in the new landscape, ' claimed an academic from an old civic university and one from a plate-glass institution. One new civic academic pointed out that if research active contracted staff can't keep up with publications they will regularly volunteer to be demoted to a teaching only contract.'

It was reported by one civic and Post 1992 universities that they had 'little to no dedicated and only centralised, administrative support', but this appears not to be the case at the other university types. Also all universities, with the exception of new, had 'a rotating Head of Department, which most felt the fairest method to appoint' commented a plate-glass academic.

All interviewees from all six institutions alluded to the so called 'audit culture' in the form of Key Performance Indicators (KPIs) prevalent in the marketised English higher education sector today. All participants regardless of academic biography (age, length of service, job 
title) felt that this culture did not sit well within an academic culture. They all voiced a dichotomy (values incongruence) between the two in terms of values, language used, priorities, intent, manner and execution. 'Management speak drives me nuts when I hear it', shudders one interviewee from a Post 1992 university. 'There is no slack built into current staffing and all managers talk about are efficiencies and targets' (reports a new civic academic).

The meaning and significance of these findings is that there are deep divisions within a deprofessionalised body of academic staff, between administrators and faculty, between managers and academic staff members within all institutions with the exception of the ancient. The most severely affected are the Post 1992 universities. The casualisation of many academic staff, especially teaching staff and the lack of administrative support have had a negative impact on $\mathrm{HE}$ as a result of the marketisation of the sector. This enforced casualisation of staff, happened in the UK retail trade 30 years ago to make the sector more efficient. Now it is happening in all parts of the HE sector for the same reasons. The result is that many academics have lost status as a teaching professional but not as a star researcher. This imbalance may be redressed with the soon to be introduced TEF in September 2017.

5. Increased incidence of performativity, bullying and work place aggression

All those interviewed regardless of institution talked of the fragmentation of an academic community not helped by the increasing casualisation of staff. Management culture in particular in Post 1992 but also in some plate-glass institutions is said to be 'controlling, threatening and aggressive'. 'We have to justify and re-justify our position and look over our shoulder' (a new civic academic). Increasingly, performativity pervades the HE sector where 'managers use rewards and implicit sanctions (threat of dismissal or redundancy) as a form of control of their academic staff' says a new civic academic. Most academic staff (in all but Oxbridge setting), who want to survive and keep their job, know 'they are not to openly question management decisions but to follow orders,' reports an academic from a technological university.

'There is aggressive marketing, more and more open days... we as staff are having to get involved or else' reports a new civic staff member.

Lecturers from most institution types interviewed recounted, either witnessing, hearing of stories within their institutions of, or experiencing themselves, bullying in the form of victimisation mainly by managers but also within academic units by those with more power and 'bigger egos' than others. In some cases it was reported that huge pay outs were involved when a determined staff member proved constructive dismissal.

One plate-glass academic said 'bullying in a university setting is sophisticated in its subtlety and covertness and survives almost undetected, except by its victims. It is inherently difficult to evidence as it most often has no witnesses... it is simply your word against that of another'. Many staff of all institution types related incidents where they were subjected to, or witnessed brief and commonplace verbal, behavioural hostile, derogatory, or negative slights and insults to disparage the target colleague or subordinate. Undermining the target's intellectual credibility, eye rolling when the target is speaking, excluding the target from work or social conversations or from formal or informal meetings, or overlooking the target for promotion were the most common forms of oppression in the university setting. 
A Post 1992 senior academic said that she had experienced herself and seen other staff suffer at the hands of more powerful academics and managers if they did not take on more and more every year. 'If staff have done more than was on their workload, there is no thanks nor recognition by line managers but... if you do not meet one criteria on the workload, staff are given other duties over the summer. Even if you have worked hard and conscientiously for years but for whatever reason you now have a challenge in your life which makes things hard for you, managers are not interested and don't care. Well, I was told: if you can't cope then you know where the door is. There is just no empathy nor understanding.'

One plate-glass academic reported that, he had been suspended, for a year by university management for 'speaking out against the management regime,' only to be reinstated after a long investigation, as it was found that there was no case to answer. He also referred to the suicide in September 2014 of Professor Stefan Grimm a biologist who held a Chair in Toxicology at Imperial College London (an old civic university). This he said was an example of the aggression and bullying of today's university managers. 'Speaking to Times Higher Education on condition of anonymity, two academics who knew Professor Grimm, who was 51, said that he had complained of being placed under undue pressure by the university in the months leading up to his death, and that he had been placed on performance review.' He was, said to be, 'struggling to fulfil the metrics' of a professorial post by his head of department. The coroner described his death as needless.

Overall, those interviewed said, that the job was more than that, it was a vocation and that many suffered from 'a culture of long working hours and presenteeism', claimed one plateglass university academic. 'It is expected that I work at weekends, during holidays and am on email 24/7', reported Post 1992 academic.

The meaning and significance of these findings is that bullying prevails in the HE sector across all institutions. However, more prevalent is the highly competitive environment of the non- ancient universities where the luxury of being financially closeted perhaps makes the difference in institutional culture, governance, administration and control. The competition for fewer resources in HE seems to have created an aggressive and performative academic work environment where bullying can thrive. Staff goodwill is rapidly diminishing as a direct consequence of performativity and the lack of compassion shown staff by management especially in the Post 1992 and plate glass universities.

\section{Work Intensification}

All academic staff regardless of institution felt they suffered from more occupational stress today due to controls and emphasis on outputs and more centralisation of administration and other services making the job of the academic more difficult. However, the most precarious, insecure and demoralised academics, suffering from stress, are those who are casual and temporary in Post 1992 universities. This regularly manifests itself in the form of 'rattiness with students or colleagues' (a new civic academic). The second most stressed group of academics are full-time permanent teaching staff at Post 1992-, technological and plate-glass universities, followed by those in the civic universities. Occupational stress was not alluded to explicitly by academics in an ancient university but they did highlight their distaste for governmental controls.

There is one key stressor particular to the Post 1992 universities for older staff who were hired pre 1992 as teaching staff only. The professional goalpost has changed. All academic 
staff at this particular Post 1992 university are to have a PhD by 2022. Staff have had to obtain part-time masters' degree and $\mathrm{PhD}$ whilst working full-time. Even younger staff who are recruited with a master's degree, 'feel coerced into doing a PhD part-time in addition to a full-time workload with a nominal 200 hours per academic year for their doctoral studies' reports an associate lecturer in her 30s in a Post 1992 university. Another Post 1992 staff member with 27 years' service reported giving up 'ten years' worth of any free time (weekends, holidays) to keep up with the new employer qualification demands and this is typical for all staff here.' This is bound to take a toll on an individual's health and wellbeing. The division between work and free time is increasingly unclear and so staff feel under constant pressure to achieve work objectives even during what should be their downtime. For some this is the cause of 'psychological burnout', where the employee can no longer function nor attend work professionally without time out and medical intervention.

There are differences in the type of students at different institutions. The most starkly challenging students go to the Post 1992 universities, where most students need lots of pedagogical and pastoral support. This is a determinant on the nature of work in these particular universities. Many reported that this is a further stressor for those Post 1992 academics.

One Post 1992 lecturer had requested reducing their hours, due to health reasons, for less pay but his manager refused point-blank. He ended up leaving his position, exhausted.

An associate lecturer at Post 1992 university, after serving seven years without being offered a permanent post, became so ill, after teaching $25+$ hours every week all academic year, she requested one week's unpaid leave just to get some rest. Her manager reluctantly agreed.

Two interviewees, one at an old civic university and one Post 1992 are both retiring early due to their increasing workload every year.

Therefore, with the exception of ancient universities, all participants reported that, they were under more pressure and are suffering from occupational stress. 'The main stressor' reported by those participants 'is an unmanageable workload.' 'There is very little time for quiet contemplation and reflection as we are constantly trying to meet deadlines and provide metrics for management.' 'There is a lot of window dressing but little substance to a lot of what we do now,' reports a post 1992 academic. The result of much of the occupational stress experienced by academic staff is manifested physically (repeated illness) and psychologically in breakdowns and/or burn out and exhaustion. 'Staff are running on empty a lot of the time and the workload model is a fiction. Our workloads have increased exponentially.' 'There is no time to easily take annual leave and to have a well-earned rest...no research time, the work keeps piling on until staff pop,' reports a Post 1992 lecturer. She goes on to say that 'people can't take it and are dropping like flies!'

'Mental resilience is needed to survive' in the current HE environment stated almost all academic staff regardless of their university type.

The meaning and significance of these findings are that the phenomenon of work intensification, extensification via increased workloads and administration does exist in our universities and this has resulted in negative traits of occupational stress and well-being for many academic staff. This trend is very worrying. 
In this study, examples of interviewees' coping strategies or resistance include the following.

'There are two types of coping strategy: do everything quickly without much thought so inevitably you miss something or you accept you cannot do everything and just do some things well and do not worry about those things that do not get done. Both ways the uni. comes off badly but that's the only two ways to cope. Some staff retire early or spend their time looking for a way out, ' comments a plate-glass academic.

A Post 1992 academic said 'I wish 'they' would just pay me off to leave-I would.'

In an old civic university an academic reported the ways in which he and others coped with and resisted the new HE context by:

'feigning absentmindedness, sarcastic remarks at meetings, subterfuge, not taking on new areas...trying to offload marking to others... whinging a bit more... avoiding big jobs...some do more consultancy work...some network more with colleagues in other institutions and some adapt and make it work for themselves...staying away from the office as much as they can.'

'Managers have shot themselves in the foot as staff are becoming more job's worth so no staff volunteering to do anything extra so flexibility lost.'

Limitations of the Research

There is a relatively small number of interviews in this study, therefore it is difficult to categorically correlate an academic biography with their opinion in the context of their university type. In addition, international staff were not interviewed, these could bring a varying perspective to the narrative found in this study. A mixed approach in further research would aid this objective.

\section{Conclusions of the Study}

The marketisation of the HE sector is an emotive topic among all academic participants. Its impacts, all reported as negative, discussed above, are compelling and far-reaching.

It would appear that the ancient university is least impacted by marketisation in terms of academic staff and the nature of their work. Next are the old and new civic universities, then the technological, plate-glass. The most impact is felt by academics in the Post 1992 universities.

Many academic staff across England feel constrained by the relentless surveillance, monitoring and target setting by management. Academics are increasingly losing their voice and control over the nature of their work as professionals. This causes unnecessary occupational stress and anxiety, which in the long-term have implications for staff health and well-being.

The researcher cannot definitively claim from this study that there is a direct correlation between the biography of an academic and their views. However, there appears to be strong negative views of the marketised HE sector, held by those who were employed in HE pre 1992, regardless of institution and discipline, and those who have experienced HE before marketisation took hold in the last 10-15 years. Those who are younger and, have known 
nothing but the marketised HE environment are still critical of it but more often than not do not hold such negative views of it.

Six key themes emerged:

\section{Efficiency and quantity over effectiveness and quality}

Most staff feel there is a worrying, dumbing down of quality where student numbers and income are prioritised. The growth in overseas numbers seems to have an impact on the nature of academic work. To cope with this increased staffing is not a priority of managers as this is not financially efficient so existing academics in all institution types are left, having to deal with new pedagogical and pastoral demands on their time. HE management appear to focus too much on economic efficiencies rather than simultaneously focussing on effectiveness in the daily realities of academic work. This theme appears to be at its most severe in Post 1992 and plate-glass universities.

\section{Autocratic, managerialist ideology over academic democracy and debate}

Since marketisation, the academic voice has been gradually eroded. This is by an increasingly remote but dictatorial management. There is little to no democracy and debate with academics in the HE sector. Decisions are simply imposed on the academics, from above with little attention to the pedagogical impact. Managers seem to be superfluous to HE requirement. Managerialism seems to have infiltrated all kinds of university with the exception of the ancient. Most severe managerialism evident in the Post 1992 universities followed by the plate-glass. It is also to some degree pervading the technological and the old and new civic universities. Ancient universities do not appear to have succumbed to this.

\section{Instrumentalism over intellectualism}

Instrumental targets, surveillance and constant checking of academic, intellectual staff by HE managers and administrators, is of concern to those in the profession. The instrumental standardisation efforts of managers of university policy appears inappropriate and inflexible for many academic purposes. Too much time and effort is spent, in the reporting to management of metrics rather than just getting on with the job in hand. The quantitative rather than the qualitative, intellectual and pedagogical aspects of the nature of academic work seem to be the subject of much dismay among all staff, regardless of their biography, and across all institution types.

\section{De-professionalism and fragmentation of the academy}

There are deep divisions within a de-professionalised body of academic staff, between administrators and faculty, between managers and academic staff members within all institutions with the exception of the ancient. The most severely affected are the Post 1992 universities. The casualisation of many academic staff, especially the teaching staff and the lack of administrative support have had a negative impact on HE as a result of the marketisation of the sector. This enforced casualisation of staff, happened in the UK retail trade 30 years ago to make the sector more efficient. Now it is happening in all parts of the HE sector for the same reasons. The result is that many academics have lost status as a teaching professional and have been marginalised. This imbalance may be redressed with the soon to be introduced TEF in 2017/18. 
5. Increased incidence of performativity, bullying and workplace aggression

Occupational stress and bullying prevail in the HE sector across all institutions. However, it is more prevalent in the highly competitive environment of the non- ancient universities where the luxury of being financially independent perhaps makes the difference in institutional culture, governance, administration and control. The competition for fewer resources in HE seems to have created a competitive, adversarial and aggressive academic work environment, especially in the Post 1992 and plate glass universities, where bullying can thrive. Staff goodwill is rapidly diminishing as a direct consequence of performativity and the lack of compassion shown staff by management. The sector has been brutalised and dehumanised. An academic dystopia has emerged.

\section{Work intensification}

The phenomenon of work intensification, due to extensification via increased workloads, and the frantic speed and pace of administration, exists in our universities and this has resulted in negative traits of occupational stress and well-being for many academic staff. This trend across the sector is very worrying. There are differences in type of students at different institutions. The most starkly challenging students go to the Post 1992 universities, where most students are from a working class background who need lots of pedagogical and pastoral support. This is a determinant on the nature of work in these particular universities. Staff reported a variety of coping strategies and forms of resistance.

In summary, the overwhelming evidence of this empirical study highlights the multi-faceted extent of the radical impact of the marketisation on the academy in English universities. There is no doubt that today's performative university with its targets and managerialism, regardless of institutional type is causing anxiety and stress among the academic profession. The only exception appears to be in the ancient universities. Further research is required to investigate what can be done to address this narrative of the decimation of the professional work of the academy. Academics are a key profession in the $21^{\text {st }}$ century. They are the creators and critics of current knowledge and its application in our society. Therefore, the concerns noted in this article need to be taken into account by public policy makers. 


\section{References:}

Ackroyd, S. and Thompson, P. (2016) Organisational Misbehaviour, 2nd fully revised and updated edition (first published by Sage publications in 1999) now with 10 chapters as compared with the original 6

Adcroft, A and Willis, R (2006) Post-Modernism, De-Professionalisation and Commodification: The Outcomes of Performance Measurement in Higher Education, Journal of Finance and Management in Public Services, Vol.6 No 1, 43-56

Alvesson, M \& Spicer, A (2016) (Un) conditional surrender? Why do professionals willingly comply with managerialism, Journal of Organisational Change Management, 29 (1), 29-45

Alvesson, M and Spicer, A (2016) The Stupidity Paradox, London: Profile Books Ltd.

Archibong, IA, Bassey, AO, and Effiom, DO (2010) Occupational Stress Sources among Academic Staff, European Journal of Educational Studies Vol 2, 3, 217-225

Ball, S J (2003) The Teachers Soul and the Terrors of Performativity, Journal of Education Policy, 18:2,215-228

BBC 1 Documentary $4^{\text {th }}$ May 2017 entitled 'The Truth about Stress'

Bathmaker, S (1999) So what's the deal? The State of the psychological contract in a new university, Journal of Vocational Education and Training, Vol.51 (2), 265-282

Baudrillard, J (2000[1970]) The Consumer Society: Myths and Structures, trans. C. Turner London, Sage

Bendix Petersen, E and Davies, B. (2010) In/Difference in the neoliberalised university. Learning and Teaching in the Social Sciences. 3:2. $92-109$

Berg, L, Huijbens E H and Larsen HG (2016) Producing Anxiety in the Neoliberal University, The Canadian Geographer Special Issue on Critical Reflections on Cultivating an Ethic of Wellness in Geography

Berg, M and Seeber, B,K (2016) The Slow Professor: Challenging the Culture of Speed in the Academy, Toronto, Canada, University of Toronto Press

Bok, D (2003) Universities in the Marketplace, Princeton, Princeton University Press

Braverman, H (1974) Labor and Capital: The Degradation of Work in the Twentieth Century, New York, Monthly Review Press

Burrows, R (2012) Living within h-index? Metric assemblages in the contemporary academy, The Sociological Review 60 (2), $355-372$

Cairns, G and Sliwa, M (2008) A very short, fairly interesting and reasonably cheap book about international business, London, Sage

Publications Ltd.

Cate, T (ed.) (2013) An Encyclopaedia of Keynesian economics, Cheltenham: Edward Elgar 
Chandler, J, Barry, J and Clark, H (2002) Stressing Academe: The wear and tear of the New Public Management, Human Relations, Vol. $55: 9,1051-1069$

Cohen, S.; Kessler, R.C.; \& Gordon, L.U. (1995) Strategies for measuring stress in studies of psychiatric and physical disorders. In Cohen, S.; Kessler, R.C.; \& Gorden, L.U. (Eds). Measuring Stress. A Guide for Health and Social Scientists. Oxford: Oxford University Press.

Couldry, N (2008) Reality TV, or the secret Theatre of Neoliberalism, Review of Education, Pedagogy, and Cultural Studies, 30 (3), 3-13

Davies, W. (2016) 'The difficulty of 'neoliberalism'. Political Economy Research Centre,

PERCblog. http://www.perc.org.uk/project_posts/the-difficulty-of-neoliberalism/ Accessed 5 ${ }^{\text {th }}$ January 2016.

Davies, B (2005) The (im)possibility of intellectual work in neoliberal regimes. Discourse: Studies in the Cultural Politics of Education 26 (1), $1-14$

Davies, B and Bendix Petersen, E (2005) 'Neo-liberal discourse in the academy: The forestalling of (collective) resistance'. Learning and Teaching in the Social Sciences 2 (2):77-98.

DeFalco, B and Crabb, P (2015) Academia Workplace Bullying; An Overview, Powerpoint slides, Pennsylvania State University Hazelton

Derber, C (1983) Managing professionals: ideological proletarization and postindustrial labor, Theory and Society, 12 (3), $309-41$

Derber, C and Schwartz,W (1983)Toward a Theory of Worker Participation, Sociological Inquiry, Vol.53 (1)

Diefenbach, T (2009) New Public Management in Public Sector Organisations, Journal of Public Administration, Vol.87, Issue 4, 892-909,

Dec. 2009

Dillow, C (2007) The End of Politics, Hampshire, Harriman House Ltd.

Docherty, T (2015) Universities at War, London, Sage Pub. Ltd.

Farnham, D (2015a) The changing Faces of Employment Relations, London, Palgrave MacMillan

Farnham, D (2015b) Human Resource Management in Context $4^{\text {th }}$ Edition, London, CIPD

Farnham, D (ed.) (1999) Managing Academic Staff in Changing University Systems: international trends and comparisons, Buckingham: Open University Press.

Ferlie, E, Ashburner, L, Fitzgerald, L and Pettigrew, A (1996) New Public Management in Action, Oxford, OUP

Fisher, S (1994) Stress in Academic Life: The metal assembly line, Buckingham, OUP

Follett, M (1940 [1918] "Dynamic Administration: The Collected Papers of Mary Parker Follett", ed. by E. M. Fox and L. Urwick ,

London: Pitman Publishing

Foucault, M (2008) The Birth of Bio-politics: Lectures at the College de France 1978-79, Basingstoke: Palgrave

Geppart, M \& Hollinshead, G (2017) Signs of dystopia and demoralization in global academia: Reflections on the precarious and destructive effects of the colonization of the Lebenswelt. Critical Perspectives on International Business, 13 (2)

23

(C) Emerald Publishing Limited

This is a pre-print of a paper and is subject to change before publication. This pre-print is made available with the understanding that it will not be reproduced or stored in a retrieval system without the permission of Emerald Publishing Limited. 
Gilbert, P (2010) The compassionate Mind, London, Constable \& Robinson Ltd.

Gill, R (2009) 'Breaking the Silence: The hidden injuries of neo-liberal academia' in Flood,

R \& Gill, R (Eds.) Secrecy and Silence in the Research Process: Feminist Reflections,

London: Routledge

Giroux, H, A (2014) Neoliberalism's War on Higher Education, Chicago, Haymarket Books

Granter, E (2009) Critical Social Theory and the End of Work, Surrey, Ashgate Publishing Ltd.

Grey, C (2013) A very short, fairly interesting and reasonably cheap book about studying organisations, London: Sage Publications

Guardian Survey ( $3^{\text {rd }}$ Nov.2014) Culture of cruelty: why bullying thrives in higher education

Haldane Report (1918) www.civilservant.org.uk

Hood, C (1991) A Public Management for all Seasons? Journal of Public Administration Vol.69 Spring 1991, 3-19

Horton, S and Farnham, D, ed. (1999) Public Management in Britain, Basingstoke, MacMillan Press Ltd.

Hill, D (ed.) (2013) Immiseration, Capitalism and Education: austerity, resistance and revolt, Brighton, The Institute for Education Policy

Jones, O (2014) The Establishment-And how they get away with it, London, Penguin Books

Kallio, K-M, Kallio, T, J, Tierni, J \& Hyvoenen, T (2016) Ethos at stake: Performance management and academic work in universities,

Human Relations, 69 (3), 685-709

Karran, T and Mallinson, L (2017, May 23 ${ }^{\text {rd }}$ ) Academic Freedom in the UK: Legal and Normative Protection in a Comparative Context-

Report for the University and College Union, University of Lincoln

Kehm, B and Teichler, U (ed.) 2014 The Academic Profession in Europe: the changing Academy, Springer Dordrecht: Heidelberg, London, NY

Klikauer, T (2013) Managerialism-A Critique of an Ideology, Basingstoke, Palgrave MacMillan

Kinman, G and Wray, S (July 2013) Higher Stress Survey of HE Staff, UCU

Kirkpatrick, A, Ackroyd, S and Walker, P (2005) The New Managerialism and Public Services Professions, NY, Palgrave MacMillan

Kinman, G (2008) A life beyond work? Job demands, work-life balance, and wellbeing in UK Academics Journal of Human Behavior in the

Social Environment

Lazarus, R S (1990) Theory-based stress measurement, Psychological Inquiry 1 (1), 3-13

24

(c) Emerald Publishing Limited

This is a pre-print of a paper and is subject to change before publication. This pre-print is made available with the understanding that it will not be reproduced or stored in a retrieval system without the permission of Emerald Publishing Limited. 
Lorenz, C (2012) If you are so smart, why are you under surveillance? Universities, neoliberalism and new public management, Critical

Inquiry, Vol.38 (3), 599-629

Lynch, K \& Ivancheva, M, P (2015) Academic Freedom and the commercialisation of universities: a critical ethical analysis, Ethics in Science and Environment politics, 15 (1), 1-15

Lynch, K (2010a) 'Neoliberalism and Marketization: the implications for higher education'.

European Educational Research Journal 5 (1):1-17

Lynch, K (2010b) Carelessness: A hidden Doxa of Higher Education, Arts and Humanities in

Higher Education Vol 9 (1), 54-67

Lynch, K (2007) Love Labour as a distinct and non-commodifiable form of care labour, Sociological Review, 1-21

Lyotard, J (1984) The Postmodern condition: a report on knowledge, Vol.10, Manchester University Press

Marini,G ( in THES August $21^{\text {st }} 2015$ ) University managerialism 'can boost academic freedom'

Choice between overarching managers and collegiality in universities a false choice, study suggests

Martin, B.R (2016) 'What's Happening to our Universities?'. Prometheus (Working Paper available from www.sussex.ac.uk/spru/swps2016-03 )

Miller ,H (1998) Managing academics in Canada and the United Kingdom, International Studies in Sociology of Education, 8:1, 3-24,

Miller, H in Smyth, J (ed.) (1995) Academic Work: The changing Labour process in Higher Education, Open University Press, Bristol, PA USA

Molesworth, M, Scullion, R and Nixon, E (2011) The Marketisation of HE and the Student as Consumer, Oxon, Routledge

Morgan, J (2015) Rowan Williams on higher education's inhuman and divisive jargon. Times Higher, January $29^{\text {th }}$, https:// www.timeshighereducation.com/news/rowan-williams-on-higher-educations-inhuman-and-divisive-jargon/2028188.article

Morrish 2015 https://academicirregularities.wordpress.com/tag/managerialism

Neave, G (1988) On the Cultivation of Quality, Efficiency and Enterprise: an overview of recent trends in Higher Education in Western Europe 1986-1988, European Journal of Education, 23 (1 and 2), 7-23

Ovetz, R (2015) Response to Jonna and Smith on LPT 40 years on, Labor Studies Journal, Vol.40 (3), 275-277

Palfreyman, D (2007) Learning and Teaching across Cultures in Higher Education,

Basingstoke, Palgrave Macmillan

Parker, M (2014) University Ltd, Organisation, Sage, Vol 21(2) 281-292

Pearson, RW (2015) Academic Identity in a performative and marketised environment: a comparative case study, PhD thesis, University of Nottingham 
Petrina, S , Mathison,S and Ross, EW (2015) Threat Convergence: The New Academic Work, Bullying, Mobbing and Freedom, Workplace:

A Journal for Academic Labour 24:58-69

Pollitt, C (1990) Managerialism and the Public Service, Oxford: Blackwell

Propper, C :www.the guardian.com/higher-education-network/blog/2013/nov/12/university Does university management matter?

Ritzer, G (2013) The McDonaldization of Society, London, Sage Publications Ltd.

Roderick, L (2016) Toxic Friday-Resources for addressing Faculty Bullying in Higher

Education, University of Alaska Anchorage

Rousseau, D and Wade-Benzoni, K (1994) Linking Strategy and Human Resource Practices: How Employee and Customer Contracts are created, Human Resource Management, Vol,33, 463-489

Rutter, H, Herzberg, J and Paice, E (2002) Stress in Doctors and Dentists who teach, Medical Education, 36,543-549

Schein, E (1965) Organizational Psychology, New Jersey: Prentice-Hall

Sikes, P (2006) Working in a 'new' University: in the shadow of the Research Assessment Exercise? Studies in Higher Education,

Vol.31:5,555-568

Smyth, J (ed.) (1995) Academic Work: The changing Labour process in Higher Education, Society for Research into Higher Education, Bristol, Open University Press

Steger, M (2010) Globalisation: The Greatest Hits, a Global Studies Reader, Boulder, Paradigm

Strathern, M (ed.) 2000.' Audit Cultures: Anthropological Studies in Accountability, Ethics

and the Academy', London: Routledge

Tapper, E and Salter, B (1995) The changing Idea of University Autonomy, Studies in Higher Education, Vol.20, 59-71

Teelken, C (2012) Compliance or Pragmatism: how do academics deal with managerialism in higher education? A comparative study in three countries, Studies in Higher Education, Vol.37:3,271-290

THES $4^{\text {th }}$ May 2017-Prof Persson Worldwide Study on what nationalities of academics are most under pressure

THES Annual Work-based Survey 2016 THES $4^{\text {th }}$ Feb 2016:42

Thomas, AB (2003) Controversies in Management: issues, debates, answers second edition

NY, Routledge

Thomas, M $6^{\text {th }}$ April VC Address at UCLan 2016

Thompson, P (2013) Financialisation and the Workplace, Work, Employment and Society, Vol 27 (3) 472-488

Thompson, P and Smith, C (2009) Labor Power and Labor Process: contesting the marginality of the sociology of work, Sociology, vol. 43 (5), 913-930

Tytherleigh, MY, Webb, C, Cooper, CL and Ricketts.C (2005) Occupational Stress in UK HEIs: a comparative study of all staff categories, Higher Education Research and Development Vol.24 (1), February 2005, 41-61 
UCU Report April 2016 Precarious Work in Higher Education: A Snapshot of insecure contracts and institutional attitudes

Visser, M (2016) Management control, accountability, and learning in public sector organisations: A critical analysis. In L. Gnan, A. Hinna

\& F. Monteduro (eds.), Governance and performance in public and non-profit organizations, Vol. 5, 575-93, Bingley, Emerald

Waring, M (2013) All in this together? HRM and the Individualisation of the Academic Worker, Higher Education Policy, Vol.26, 397-419

Wilsdon, J (2015) The Metric Tide: Report of the Independent Review of the Role of Metrics in Research Assessment and Management DOI 10, HEFCE Review July 2015

Wilson, T (1991) The proletarianisation of academic labour, Industrial Relations Journal, Vol.22, 250-262

Williams, R (2016) A nervous breakdown in the body politic, New Statesman $1^{\text {st }}$ May

http://www.newstatesman.com/politics/uk/2016/05/nervous-breakdown-body-politic

Winefield, AH, Boyd, C, Saebel, J and Pignata, S (2008) Job Stress in University Staff-An Australian Research Study, Sydney, Australian Academic Press

Wilson, M and Holligan, C (2013) Performativity, Work-related emotions and collective research Identities in UK university education

departments: An Exploratory Study, Cambridge Journal of Education, Vol43:2, 223-241

Winefield ,A and Jarrett, R (2001) Occupational Stress in University Staff, International Journal of Stress Management, Vol 8, 4, 285-298

Winefield, A, Gillespie, N, Stough, C, Dua, J ,Hapuarachchi, J and Boyd, C (2003) Occupational Stress in Australian University Staff from a National Survey, International Journal of Stress Management Vol 10 No 1 51-63

Winter, R (1995) The University Life PLC: the industrialisation of higher education in J. Smyth (ed.) Academic Work: the changing labour process in higher education, Buckingham: Open University Press

www.en.oxforddictionaries.com/definition/managerialism accessed 10th July 2017

www.research.omicsgroup.org/index.php/List_of_UK_universities_by_date_of_foundationaccessed 10th July 2017

www.theguardian.com > Society > Public sector pay $3^{\text {rd }}$ July 2017

www.thetimeshighereducation.com/news/uk--university-pension-scheme-deficit 26th July 2017

Young, M. F. D. and Beck, J., 2005. The assault on the professions and the restructuring of academic and professional identities: a Bernsteinian analysis. British Journal of Sociology of Education, 26 (2), pp. 183-197.

\section{Further Reading}

Prof. Clegg S (2017) Key note speaker at $10^{\text {th }}$ International CMS Conference Liverpool July 2017-'What has happened and what is to be done?'. Clegg talks of the notion of worker 'self-exploitation', 'the rise of impersonalism and the dehumanisation of society', the decline of citizenship in favour of entreprenuerialism' and 'profit versus ethics' in postmodern organisations.

Davies, J and Farrell, M (2016) The Market Oriented Universitv, Cheltenham: Edward Elgar Publishing Limited 
(C) Emerald Publishing Limited

This is a pre-print of a paper and is subject to change before publication. This pre-print is made available with the understanding that it will not be reproduced or stored in a retrieval system without the permission of Emerald Publishing Limited. 